\title{
Using an Attapulgite-Activated Carbon Composite Ceramisite Biofilter to Remove Dibutyl Phthalate from Source Water
}

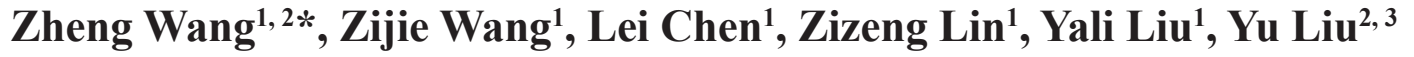 \\ ${ }^{1}$ School of Civil Engineering, Nanjing Forestry University, 159 Longpan Road, Nanjing 210037, China \\ ${ }^{2}$ Advanced Environmental Biotechnology Centre, Nanyang Environment and Water Research Institute, \\ Nanyang Technological University, 1 Cleantech Loop, Singapore 637141, Singapore \\ ${ }^{3}$ School of Civil and Environmental Engineering, Nanyang Technological University, \\ 50 Nanyang Avenue, Singapore 639798, Singapore
}

Received: 20 June 2017

Accepted: 19 August 2017

\begin{abstract}
This study developed an attapulgite-activated carbon composite ceramisite (AACCC) biofilter for removing trace-level dibutyl phthalate (DBP) from micro-polluted drinking source water. Total pore area and average pore diameter of AACCC were estimated to be $112.2 \mathrm{~m}^{2} / \mathrm{g}$ and $19.8 \mathrm{~nm}$, respectively, while the AACCC showed considerable adsorptive capacity due to its mesoporous structure, i.e., it would be used as an ideal filtration media. Although AACCC could adsorb DBP, biological AACCC covered by different types of microorganisms appeared to be more effective in removing DBP from source water. At a filtration velocity of $2 \mathrm{~m} / \mathrm{h}$ during two influent concentrations $(20 \mu \mathrm{g} / \mathrm{L}$ and $50 \mu \mathrm{g} / \mathrm{L})$, the DBP removals in AACCC biofilter were higher than the AACCC filter, being $1.2 \mu \mathrm{g} / \mathrm{L}$ and $1.9 \mu \mathrm{g} / \mathrm{L}$. The pseudo-first-order kinetic model can serve as a good method for estimating removal performance of DBP using an AACCC biofilter. This clearly demonstrated the potential of the AACCC biofilter as a cost-effective and high-efficiency process for removing trace-level DBP from drinking source water.
\end{abstract}

Keywords: attapulgite-activated carbon composite ceramisite (AACCC), biofilter, dibutyl phthalate (DBP), pseudo-first-order kinetic model

\section{Introduction}

Phthalates are a class of refractory synthetic chemicals widely used for increasing the plasticity and toughness of industrial and consumer products [1]. The global production and consumption of phthalates are estimated to be more than 5 million tons in 2010

*e-mail: wangzheng@njfu.edu.cn
[2]. Phthalates are not covalently bound to the host polymer molecules. Presently, the water environment is a major sink of phthalates originating from discharge of wastewater effluent and landfill leachate, and various kinds of phthalates have been detected in many rivers and lakes ranging from 10 to $100 \mu \mathrm{g} / \mathrm{L}$ [3-4]. In the family of phthalates, dibutyl phthalate (DBP) is one of the most widely used, with global demand increasing. As a result, DBP at $15.6 \pm 0.8 \mu \mathrm{g} / \mathrm{L}$ had been found in drinking source water [4-5]. DBP has been demonstrated 
to possess reproductive toxicities and lead to metabolism dysfunction in animals, and causing endocrine disruption and carcinogenic effects in people [6]. In fact, DBP has been listed as an environmental priority pollutant by the United States Environmental Protection Agency, the European Environment Agency, and the Ministry of Environmental Protection of China [7]. In addition, the testing work of this kind of trace micropollutant in water works is not regular [4]. Therefore, a simple, effective, and adaptable changed DBP removal process from drinking source water is urgently needed.

As an emerging micropollutant, DBP can be removed through adsorption and advanced oxidation, such as combined ozonation with ultraviolet irradiation and homogeneous sono-photo-Fenton, etc. [8-9]. On the other hand, many microorganisms with the ability of degrading DBP have been isolated from different sources, such as Bacillus sp. [10], Sphingobium sp. [11], and Camelimonas sp. [12]. A biofilter with granular filter materials has been considered as a viable option for drinking water treatment, allowing for microorganisms in the source water to attach to the media surface [13]. It had been reported that various kinds of emerging organic pollutants could be removed in biofilters, including geosmin [14], 17 $\beta$-estradiol [15], mecoprop, bentazone, glyphosate, p-nitrophenolat [16], dimethylamine [17], and carbofuran [18], etc. Although granular activated carbon (GAC) has been widely used as filter media [14-15], its high cost and potential loss during backwashing are hurdles for its direct application in a rapid filter. Obviously, there is a strong need for developing a novel type of mineral adsorbent for biofiltration.
Attapulgite as largely available cheap and safe clay mineral in China has been shown to have good adsorption capacity [19]. In order to further improve the property of attapulgite, granualr attapulgite-activated carbon composite ceramisite (AACCC) was developed in this study and further used as media in biofilter for removing DBP from drinking source water. Therefore, the main objective of this study was to demonstrate the feasibility of using a biofilter packed with AACCC for removing trace-level DBP from micro-polluted drinking source water. The difference of DBP removal efficiency between non-biofilter and biofilter was systematically studied. The reactor operating conditions included adjusting the filtration rates and influent DBP concentrations. The DBP removal rate of different heights in non-biofilter and biofilters was also analyzed. Scanning electron microscopy (SEM) analysis of a different depth's AACCC in biofilter provide insight into the range of conditions conducive to biological DBP removal in surface water treatment plants. A pseudo-first-order kinetic model was used to estimate DBP removal performance in AACCC biofilter. It is expected that this study may offer an alternative for organic micropollutants from source water.

\section{Materials and Methods}

\section{Preparation of AACCC}

Attapulgite-activated carbon composite ceramisites were made from attapulgite powder (100 mesh) with

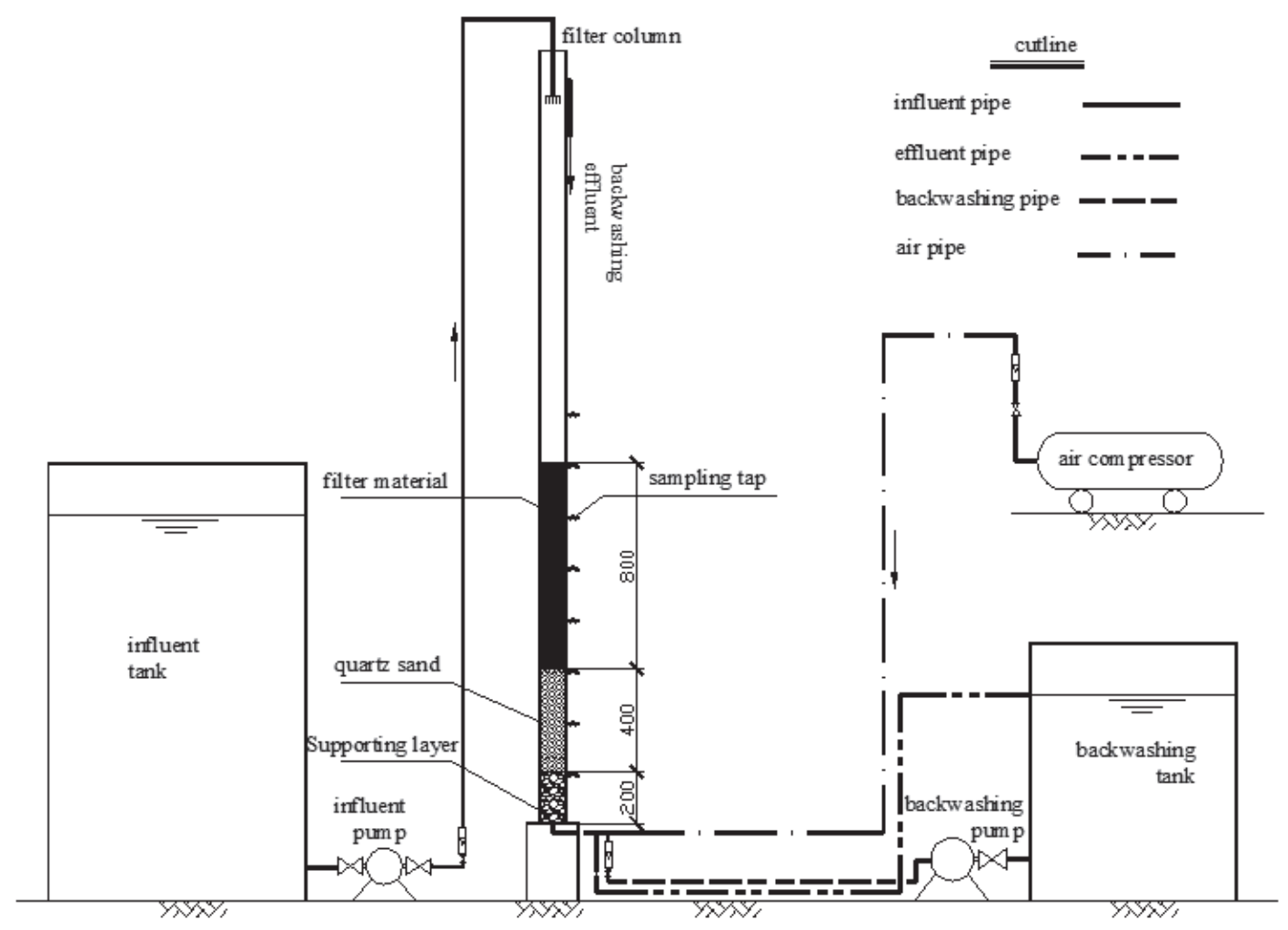

Fig. 1. Schematic diagram of the pilot system. 
the addition of $20 \mathrm{wt} \%$ of activated carbon powder (100 mesh). These two materials were first mixed thoroughly to obtain granular raw material. The granular raw material was fed to a disc granulator for producing spherical semi-finished ceramisites with the addition of about $5 \mathrm{wt} \%$ of $10 \mathrm{wt} \%$ sodium silicate solution as adhesive. After which the ceramic particles were dried at $100{ }^{\circ} \mathrm{C}$ for two hours, followed by further drying for 1.5 hours in the furnace with a temperature increase of $5^{\circ} \mathrm{C} / \mathrm{min}$ to $450^{\circ} \mathrm{C}$. For the next step the finished attapulgite composite ceramisites were cooled to ambient temperature naturally. The load process was done under flow of nitrogen $(500 \mathrm{~mL} / \mathrm{min})$. Lastly, the AACCC was thoroughly washed with distilled water until a neutral $\mathrm{pH}$ was obtained [19].

\section{Pilot System}

The experimental set-up was presented in Fig. 1. The filter column had an inner diameter of $10 \mathrm{~cm}$ and $300 \mathrm{~cm}$ height, with a $20 \mathrm{~cm}$ gravel layer. Sampling ports were arranged upon the gravel layer at an interval of $20 \mathrm{~cm}$. The upper part of the filter was packed with $80 \mathrm{~cm}$ of AACCC $\left(\mathrm{d}_{10}=3.0 \mathrm{~mm}, \mathrm{~K}_{80}=1.1\right)$ and the lower part was filled with $40 \mathrm{~cm}$ of quartz sand $\left(\mathrm{d}_{10}=1.0 \mathrm{~mm}, \mathrm{~K}_{80}=1.3\right)$.

A stock DBP solution of $10 \mathrm{~g} / \mathrm{L}$ was prepared from dibutyl phthalate with $99 \%$ of purity (99\% purity, $\mathrm{C}_{16} \mathrm{H}_{22} \mathrm{O}_{4}$, FW: 278.34, AccuStandard Inc, USA) dissolved with methanol. The feed water with different DBP concentrations was prepared from the stock DBP solution by appropriate dilutions. The filter was first fed with the DBP-loaded tap water free of microorganisms to evaluate DBP removal through AACCC adsorption, and the operation lasted for 25 days. The mixed polluted river water and water according to a volumetric ratio of 1:20 was used as the feed water to the AACCC filter operated at $4 \mathrm{~m} / \mathrm{h}$ for 90 days. This allowed for the growth of microorganisms on the AAACC, after which DBP was added to the mixed water to the AACCC biofilter, which was run for another 35 days. Air-water backwashing was conducted every 3-5 days. Water samples for DBP determination were collected at least $6 \mathrm{~h}$ after each backwashing to allow reactor performance to stabilize.

\section{Analytical Methods}

AACCC was characterized in terms of pore surface area and the pore size distribution by a mercury porosimeter (Autopore 9500, Micromeritics Instrument, USA). The scanning electron microscope (Quanta 200, Fei Instrument, Holland) was used for observation of biofilm development on the used AACCC.

Solid phase extraction was used to pre-concentrate DBP from the water samples. For this purpose, a solid phase extraction column (HC-C18 SPE, ANPEL Laboratory Technologies (Shanghai) Inc., China) was soaked in methanol for $5 \mathrm{~min}$ and quickly rinsed with $5 \mathrm{~mL}$ deionized water. $100 \mathrm{~mL}$ of water sample was added to the solid phase extraction column at a flow rate of $2 \mathrm{~mL} / \mathrm{min}$. Lastly, pre-concentrated DBP was eluted from the solid phase extraction column with $10 \mathrm{~mL}$ of methanol at a elution rate of $2 \mathrm{~mL} / \mathrm{min}$ and was further concentrated to $2 \mathrm{~mL}$ using a nitrogen blowing instrument (DC24H, ANPEL Laboratory Technologies (Shanghai) Inc., China). The concentration of DBP was analyzed by a high-performance liquid chromatograph (HPLC, Model LaChrom Elite L-2000, Hitachi Instrument, Japan) using a HITACHI LaChrom C18 (5 $\mu \mathrm{m}) 4.6$ mm I.D. $\times 150 \mathrm{~mm}$ separation column at $202 \mathrm{~nm}$ wavelength. The mobile phase was a mixture of water and methanol (10:90, v/v), and the flow rate was $1.0 \mathrm{~mL} \cdot \mathrm{min}^{-1}$. The injection volume was $10 \mu \mathrm{L}$, and column temperature was $30^{\circ} \mathrm{C}$. Under this chromatographic condition, baseline separation for DBP could be obtained within $15 \min$ [1].

\section{Results and Discussion}

\section{Characterizing AACCC}

The AACCC had a total intrusion volume of 0.48 $\mathrm{mL} / \mathrm{g}$, total pore area of $112.2 \mathrm{~m}^{2} / \mathrm{g}$, and average pore diameter of $19.8 \mathrm{~nm}$, which is much larger than that of GAC. This in turn showed the mesoporous structure of AACCC in the range of $2 \mathrm{~nm}<\mathrm{d}<50 \mathrm{~nm}$. AACCC has considerable adsorptive capacity due to its high pore areato-intrusion volume [19]. Microbial activity on AACCC extends the adsorption capacity via in situ regeneration of adsorption sites through the biodegradation of previously adsorbed organic matter [20]. The bacteria outside and inside AACCC are conducive to reducing the impact of hydrodynamic shear stress on biofilm cell density and holding stable biodegradation ability [21]. Based on previous research, AACCC is suitable for filtration media of biofilter [19].

\section{Adsorption of DBP by AACCC Filter}

The adsorption capacity of AACCC was examined in the filter fed with DBP-loaded tap water. The filter was operated with the two different influent DBP concentrations of $20 \mu \mathrm{g} / \mathrm{L}$ and $50 \mu \mathrm{g} / \mathrm{L}$ at various filtration velocities of $2,4,6$, and $8 \mathrm{~m} / \mathrm{h}$, corresponding to an empty bed contact time (EBCT) of 24, 12, 8, and 6 min, respectively. After each change in influent concentration or filtration rates, at least $24 \mathrm{~h}$ passed through the reactor before effluent water samples were collected from 20, 40, 60 , and $80 \mathrm{~cm}$ deep sample ports. No change in effluent DO was observed during the AACCC filter operation phase. The DBP concentration profiles against the filter depth are presented in Fig. 2.

As a typical adsorptive-type filter media reactor, the AACCC filter can effectively remove DBP from source water under these operating conditions. Effluent DBP concentrations appeared to be responding to the changes of filtration rates and influent DBP concentrations from different depths. Their values increased from 6.5, 9.7, and 10.0 to $10.3 \mu \mathrm{g} / \mathrm{L}$ (removal rates $=67.5,51.5,50$, 
and $48.5 \%$ ), corresponding to the four filtration velocity of being $2,4,6$, and $8 \mathrm{~m} / \mathrm{h}(\mathrm{EBCT}=24,12,8$, and $6 \mathrm{~min}$ ) under $20 \mu \mathrm{g} / \mathrm{L}$ influent concentration. Under a $50 \mu \mathrm{g} / \mathrm{L}$ high-dose DBP influent concentration, effluent DBP values increased from 28.1, 31.2, 33.5, to $36.1 \mu \mathrm{g} / \mathrm{L}$ (removal rates $=43.8,37.6,33$, and $27.8 \%$ ), corresponding to these four filtration velocities and EBCTs. Removed DBP concentrations were $13.5 \mu \mathrm{g} / \mathrm{L}$ and $21.9 \mu \mathrm{g} / \mathrm{L}$ during $20 \mu \mathrm{g} / \mathrm{L}$ and $50 \mu \mathrm{g} / \mathrm{L}$ of influent DBP concentration under $2 \mathrm{~m} / \mathrm{h}$ filtration velocity. Under all of these four filtration rates, the upper $20 \mathrm{~cm}$ AACCC filter layer played a considerable role compared the remaining $60 \mathrm{~cm}$ filter layer at the two influent DBP concentrations. It appeared that higher influent concentration gradients of DBP produce higher quality transmission force from fluid to surface and interior of AACCC [19]. Filtration velocities and EBCTs have significant impact on DBP removal at these two influent concentrations. This is because for contaminants at low levels the mass transfer in external film diffusion is often the time-limiting step, as the surface diffusion is often fast [15].
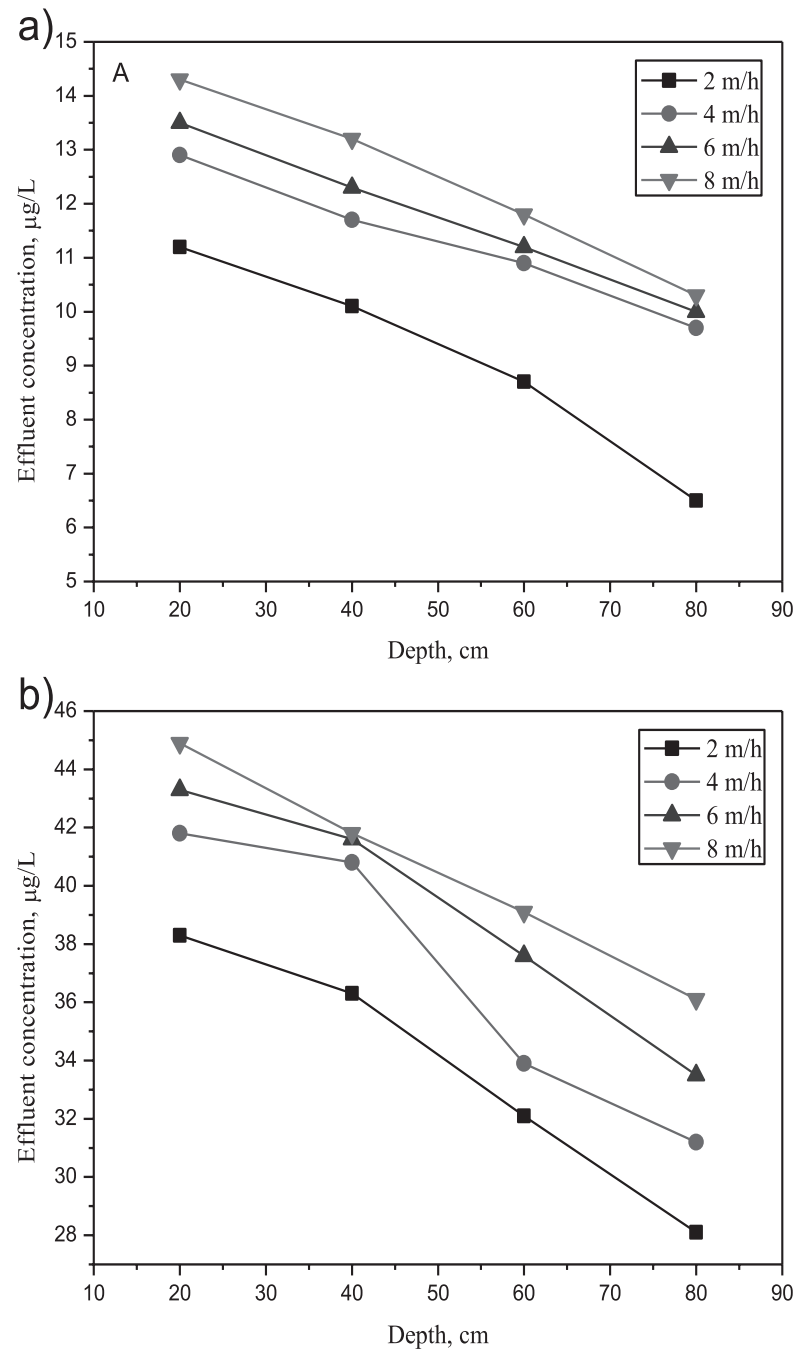

Fig. 2. Different depths of effluent DBP concentrations of AACCC filter: a) influent $\mathrm{DBP}=20 \mu \mathrm{g} / \mathrm{L}$ and b) Influent $\mathrm{DBP}=50 \mu \mathrm{g} / \mathrm{L}$.

\section{SEM Observation at Different Depths of AACCC Biofilter}

At the latter stage of the second operational period, the average permanganate index and ammonia removal rates of AACCC biofilter were fairly constant at $22-26 \%$ and $63-75 \%$ under average influent permanganate index and ammonia being $4.2 \mathrm{mg} / \mathrm{L}$ and $0.93 \mathrm{mg} / \mathrm{L}$, respectively. According to previous research of biologically activated carbon (BAC), the adsorptive sites of AACCC had eventually become saturated with organic matters in influent and AACCC filter transferred to biofilter gradually. Acclimation with the local water being treated is advantageous as the indigenous bacterial populations will be the ones that are the most efficient in utilizing the mixture of the natural organic molecules present in the water [20].
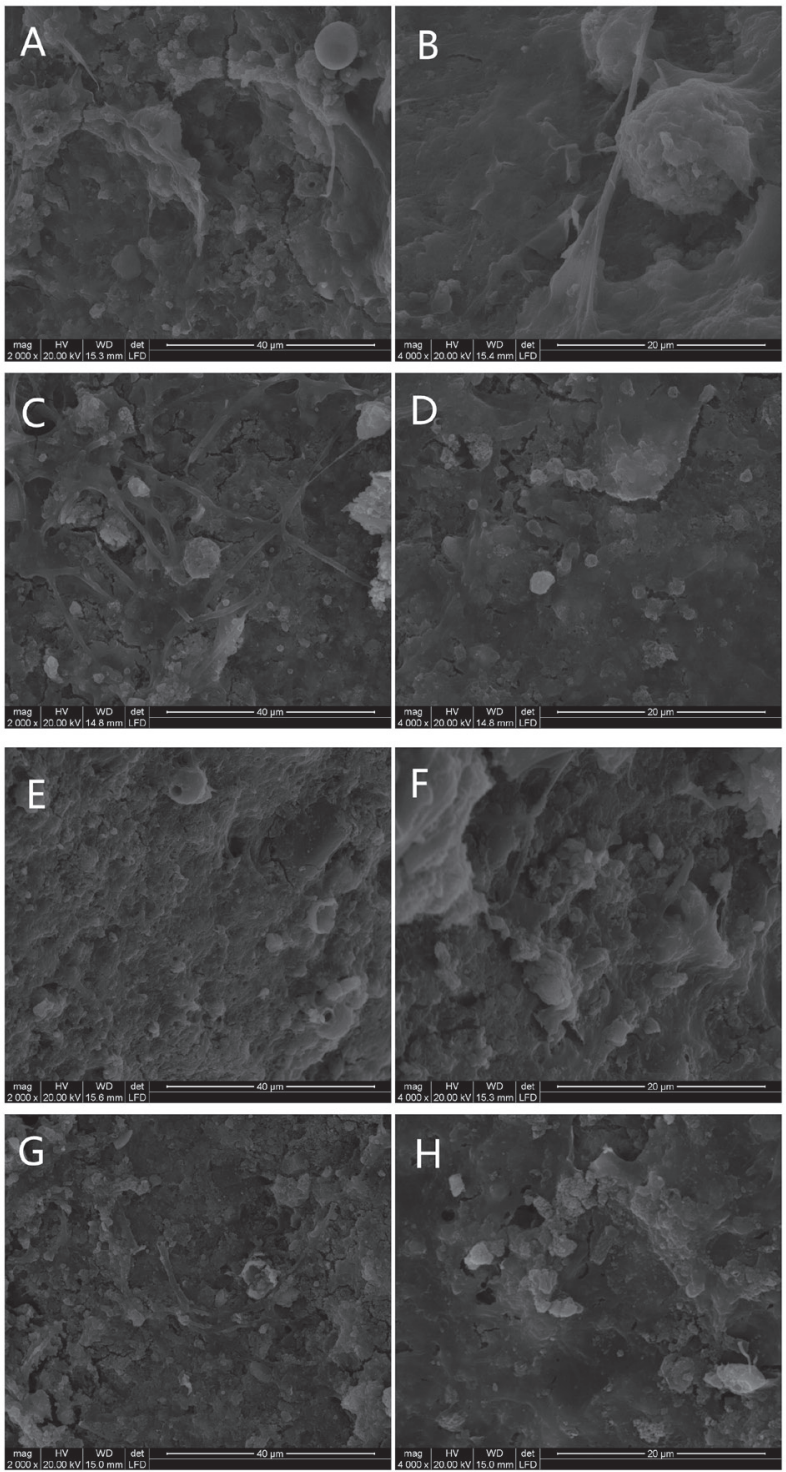

Fig. 3. SEM images of AACCC in the biofilter at different depths: A $(2,000 \times)$ and $\mathrm{B}(4,000 \times)(20 \mathrm{~cm}), \mathrm{C}(2,000 \times)$ and D $(4,000 \times)(40 \mathrm{~cm}), \mathrm{E}(2,000 \times)$ and $\mathrm{F}(4,000 \times)(60 \mathrm{~cm})$, and $\mathrm{G}$ $(2,000 \times)$ and $\mathrm{H}(4,000 \times)(80 \mathrm{~cm})$. 
Fig. 3 presents the SEM photographs at different depths $(20,40,60$, and $80 \mathrm{~cm})$ of AACCC biofilter. Results show that colonization caused by microorganisms was observed in the column at different depths. The high surface and reasonable pore size distribution of the AACCC help in the adsorption and attachment of microorganisms. From the SEM, we could see that colonized microorganisms included various bacteria, such as rods, cocci, and filamentous bacteria. Moreover, more microbial colonization occurred at upper depths in the column. This could be due to the matrix concentration variations along the flow path [22-23]. Interception of the AACCC filter layer also played a key function in the colonized microorganism's distribution in the reactor. The acclimation and more biodegradable organics could cause the variations in microbial populations [24-25]. The overall bacterial community structure, key biofilmforming bacteria, and potential respiration rate differed between different filter materials used for water treatment, but also exhibited clear changes in the structure with time and space [26-27]. From SEM at different depths,
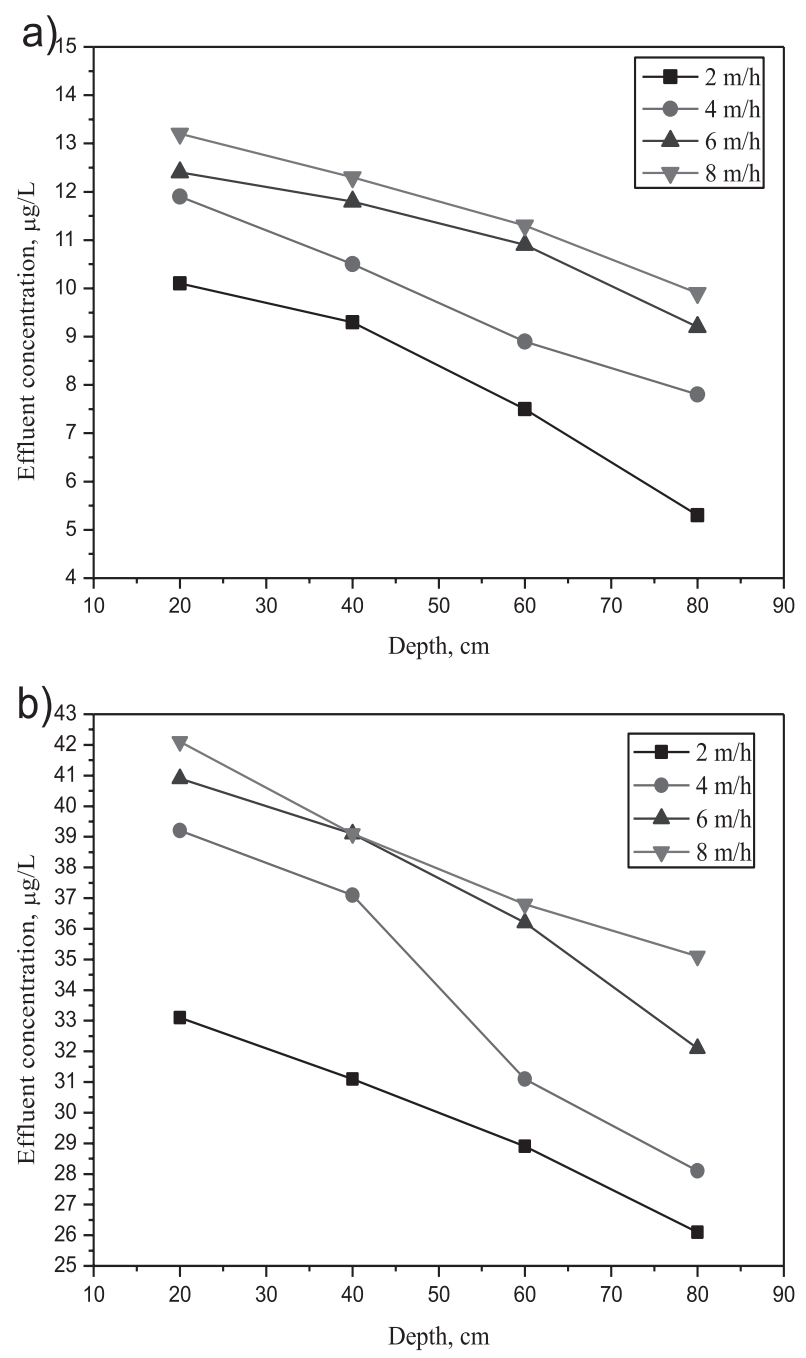

Fig. 4. Different depths of effluent DBP concentrations of AACCC biofilter: a) influent $\mathrm{DBP}=20 \mu \mathrm{g} / \mathrm{L}$ and b) Influent $\mathrm{DBP}=50 \mu \mathrm{g} / \mathrm{L}$. we could also find that the surface of the AACCC is not totally covered by the biofilm, and that the free areas might still take part in adsorption/desorption processes, leading to an increased flux of pollutants to the biofilm [28].

\section{DBP Removal in AACCC Biofilters}

At biodegradation of the DBP phase, the AACCC biofilter was fed with micro-polluted water containing added $20 \mu \mathrm{g} / \mathrm{L}$ and $50 \mu \mathrm{g} / \mathrm{L}$ DBP with a series of influent filtration velocities of $2,4,6$, and $8 \mathrm{~m} / \mathrm{h}$. After each change in influent concentrations or filtration rates, at least $24 \mathrm{~h}$ passed through the reactor before effluent water samples were collected from 20, 40, 60, and $80 \mathrm{~cm}$ deep sample ports. Effluent DO saw a significant decrease during the AACCC biofilter operation phase. The different depth effluent DBP concentrations are presented in Fig. 4.

Compared to the adsorptive AACCC filter, the AACCC biofilter can more effectively remove DBP from source water under these operating conditions. Their effluent concentration values increased from 5.3, 7.8, and 9.2 to $9.9 \mu \mathrm{g} / \mathrm{L}$ (removal rate $=73.5,61.0$, 54.0 , and $50.5 \%$ ), corresponding to the four filtration velocities of $2,4,6$, and $8 \mathrm{~m} / \mathrm{h}(\mathrm{EBCT}=24,12,8$, and $6 \mathrm{~min}$ ) under $20 \mu \mathrm{g} / \mathrm{L}$ influent concentration. When DBP influent concentration is $50 \mu \mathrm{g} / \mathrm{L}$, the effluent DBP values increased from 26.2, 28.1, 32.0, to 35.1 $\mu \mathrm{g} / \mathrm{L}$ (removal rates $=47.6,43.8,36.0$, and 29.8\%), corresponding to these four filtration velocities and EBCTs. Removed DBP concentrations were $14.7 \mu \mathrm{g} / \mathrm{L}$ and $23.8 \mu \mathrm{g} / \mathrm{L}$ during $20 \mu \mathrm{g} / \mathrm{L}$ and $50 \mu \mathrm{g} / \mathrm{L}$ of influent DBP concentration under $2 \mathrm{~m} / \mathrm{h}$ filtration velocity. The removed DBP of AACCC biofilter under $2 \mathrm{~m} / \mathrm{h}$ filtration velocity during these two influent concentrations were higher than the AACCC filter at $1.2 \mu \mathrm{g} / \mathrm{L}$ and $1.9 \mu \mathrm{g} / \mathrm{L}$. This suggested that the potential for DBP removal by drinking water AACCC biofilter would be predominantly through adsorption processes, despite high concentrations of competing organics and nutrients in micro-polluted source water [29]. A large proportion of the DBP removal occurred within the first $20 \mathrm{~cm}$ of the columns at different EBCTs and influent DBP concentrations. This is expected since most of the physical-chemical mechanisms and biological activity occurs at the top of the AACCC biofilter.

In fact, microbial presence at different depths of the biofilter can be seen in Fig. 3, which further contributed to the observed DBP removal in addition to its adsorption by AACCC. Such biological AACCC possesses the function of self-regeneration through biodegradation of adsorbed DBP on AACCC. Moreover, extracellular polymeric substances by the fixed biomass on AACCC may contribute to bioadsorption of DBP [30]. Further study will be designed to look into the respective contributions of biodegradation and adsorption toward the observed DBP removal in the biofilter. 
Table 1. $\mathrm{k}^{\prime}$ values as determined at various EBCTs

\begin{tabular}{|c|c|c|}
\hline EBCT (min) & $\begin{array}{c}\text { k' at influent DBP } \\
\text { of } 20 \mu \mathrm{g} / \mathrm{L}\end{array}$ & $\begin{array}{c}\text { k' at influent DBP } \\
\text { of } 50 \mu \mathrm{g} / \mathrm{L}\end{array}$ \\
\hline 24 & 0.055334 & 0.026928 \\
\hline 12 & 0.039234 & 0.024011 \\
\hline 8 & 0.032355 & 0.018595 \\
\hline 6 & 0.0293 & 0.014743 \\
\hline
\end{tabular}

\section{Modeling DBP Biodegradation}

As described above, the biofilter with AACCC offers an efficient and feasible option for DBP removal from micro-polluted source water at various EBCTs, which is common due to fluctuation of the influent flow rate in practice [31]. In fact, it has been well recognized that EBCT has a significant impact on biofilter performance in terms of target contamination removal and microbial community structure [32].

The target micropollutant concentration is often much lower than that of the primary substrate in micropolluted source water. As such, micropollutants can be utilized as secondary substrates by microorganisms and eventually undergo cometabolism in the biofilters. It has been proposed that micropollutant removal in steady-state biofilters treating micro-polluted source water can be described by a pseudo-first-order kinetic model when the primary substrate is present at a concentration much higher than that of target micropollutants [13]:

$$
\mathrm{C}_{\mathrm{e}} / \mathrm{C}_{0}=\exp \left(-\mathrm{k}^{\prime} \cdot \mathrm{EBCT}\right)
$$

...where $\mathrm{C}_{0}$ and $\mathrm{C}_{\mathrm{e}}$ are influent and effluent micropollutant concentrations $(\mu \mathrm{g} / \mathrm{L}), \mathrm{EBCT}$ is in $\mathrm{min}$, and $\mathrm{k}^{\prime}$ is the pseudo-first-order rate constant $\left(\mathrm{min}^{-1}\right)$. The $\mathrm{k}^{\prime}$ values for the two influent DBP concentrations were determined from Eq. 1 at various EBCTs (Table 1).

According to Howard et al. [33], the $\mathrm{k}^{\prime}$ values can be classified into four categories with regard to biodegradability of target micropollutant: recalcitrant $\left(\mathrm{k}^{\prime}<0.022 \mathrm{~min}^{-1}\right)$, slow degradation $\left(0.022 \mathrm{~min}^{-1}<\mathrm{k}^{\prime}\right.$ $\left.<0.093 \mathrm{~min}^{-1}\right)$, fast degradation $\left(0.093 \mathrm{~min}^{-1}<\mathrm{k}^{\prime}<\right.$ $\left.0.248 \mathrm{~min}^{-1}\right)$, and very fast degradation $\left(\mathrm{k}^{\prime}>0.248 \mathrm{~min}^{-1}\right)$. These guidelines suggest slow biodegradation of DBP at $20 \mu \mathrm{g} / \mathrm{L}$ concentration regardless of the EBCTs studied. However, for $50 \mu \mathrm{g} / \mathrm{L}$ DBP, its degradation behaved like a recalcitrant at the shorter EBCTs of 8 and $6 \mathrm{~min}$, probably due to insufficient reaction time in the biofilter, which was supported by the observed slow degradation at the longer EBCTs of 24 and $12 \mathrm{~min}$. The AACCC drinking water biofilter has the potential to be an effective process for the control of DBP, and a pseudo-first-order kinetic model can serve as a good method for estimating removal performance [13].

\section{Conclusions}

This study showed that the attapulgite-activated carbon composite ceramisite (AACCC) with mesoporous structure and considerable adsorptive capacity can be used as an excellent biofilter media for treating micropolluted source water. It was demonstrated that the performance of the biofilter was better than the adsorptive filter in removing trace-level DBP. The observed removal of DBP in the biofilter packed with AACCC could be attributed to physic-chemical adsorption and biodegradation at a reasonable EBCT. It is reasonable to consider that even in the presence of competing soluble organic matter in micro-polluted source water, the biofilter with AACCC has clearly shown its potential and effectiveness in removing trace-level DBP. The pseudo-first-order kinetic model can serve as a good method for estimating removal performance of DBP using an AACCC biofilter. This study indeed offers a simple and cost-effective option for new waterworks as well as for upgrading existing waterworks if DBP or related trace-level organics need to be handled.

\section{Acknowledgements}

The authors express their sincere gratitude for financial support from the National Natural Science Foundation of China (51608272), the Housing and Urban and Rural Construction Technology Program of the Ministry of Science and Projects (2016-K4-65), and a project funded by the Priority Academic Program Development of the Jiangsu Higher Education Institutions (PAPD).

\section{References}

1. WANG Z., Efficient adsorption of dibutyl phthalate from aqueous solution by activated carbon developed from phoenix leaves. International Journal of Environmental Science and Technology. 12 (6), 1923, 2015.

2. GUO Y., ZHANG Z.F., LIU L.Y., LI Y.F., REN N.Q., KANNAN K. Occurrence and profiles of phthalates in foodstuffs from China and their implications for human exposure. Journal of Agricultural and Food Chemistry. 60 (27), 6913, 2012.

3. LIU X.W., SHI J.H., BO T., ZHANG H., WU. W, CHEN Q.C., ZHAN X.M. Occurrence of phthalic acid esters in source waters: a nationwide survey in China during the period of 2009-2012. Environmental Pollution. 184, 262, 2014.

4. HUANG G.L., SUN H.W., SONG Z.H. Interactions between dibutyl phthalate and aquatic organisms. Bulletin of Environmental Contamination and Toxicology. 63 (6), 759, 1999.

5. HU X.X., SHI W., WEI S., ZHANG X.W., FENG J.F., HU G.J., CHEN S.L., GIESY J.P., YU H.X. Occurrence and potential causes of androgenic activities in source 
and drinking water in China. Environmental Science \& Technology. 47 (18), 10591, 2013.

6. PANT N., KUMAR G., UPADHYAY A.D., PATEL D.K., GUPTA Y.K., CHATURVEDI P.K. Reproductive toxicity of lead, cadmium, and phthalate exposure in men. Environmental Science and Pollution Research. 21 (18), 11066, 2014.

7. LI F.M., WU M., YAO Y., ZHENG X., ZHAO J., WANG Z.Y., XING B.S. Inhibitory effects and oxidative target site of dibutyl phthalate on Karenia brevis. Chemosphere. 130, 32, 2015

8. WANG L., FU G.Y., ZHAO B., ZHANG Z.H., GUO X.F., ZHANG H.W. Degradation of di-n-butyl phthalate in aqueous solution by the $\mathrm{O}^{3} / \mathrm{UV}$ process. Desalination and Water Treatment. 52 (4-6), 824, 2014.

9. XU L.J., CHU W., GRAHAM N. Degradation of di-nbutyl phthalate by a homogeneous sono-photo-Fenton process with in situ generated hydrogen peroxide. Chemical Engineering Journal. 240, 541, 2014.

10. YUAN S.Y., HUANG I.C., CHANG B.V. Biodegradation of dibutyl phthalate and di-(2-ethylhexyl) phthalate and microbial community changes in mangrove sediment. Journal of Hazardous Materals. 184, 826, 2010.

11. WHANGSUK W., SUNGKEEREE P., NAKASIRI M., THIENGMAG S., MONGKOLSUK S., LOPRASERT S. Two endocrine disrupting dibutyl phthalate degrading esterases and their compensatory gene expression in Sphingobium sp. SM42. International Biodeterioration \& Biodegradation. 99, 45, 2015.

12. CHEN X., ZHANG X.L., YANG Y., YUE D.M., XIAO L., YANG L.Y. Biodegradation of an endocrinedisrupting chemical di-n-butyl phthalate by newly isolated Camelimonas sp and enzymatic properties of its hydrolase. Biodegradation 26 (2), 171, 2015.

13. ZEARLEY T.L., SUMMERS R.S. Removal of trace organic micropollutants by drinking water biological filters. Environmental Science \& Technology. 46 (17), 9412, 2012.

14. SCHARF R.G., JOHNSTON R.W., SEMMENS M.J., HOZALSKI R.M. Comparison of batch sorption tests, pilot studies, and modeling for estimating GAC bed life. Water Research. 44 (3), 769, 2010.

15. LI Z.T., DVORAK B., LI X. Removing 17 beta-estradiol from drinking water in a biologically active carbon (BAC) reactor modified from a granular activated carbon (GAC) reactor. Water Research. 46 (9), 2828, 2012.

16. HEDEGAARD M.J., ALBRECHTSEN H.J. Microbial pesticide removal in rapid sand filters for drinking water treatment - Potential and kinetics. Water Research. 48, 71, 2014.

17. LIAO X.B., CHEN C., ZHANG J.X., DAI Y., ZHANG X.J., XIE S.G. Dimethylamine biodegradation by mixed culture enriched from drinking water biofilter. Chemosphere. 119, 935, 2015.

18. WANG X., LIU L., YAO M.Q., ZHANG H.W., BAO J. Degradation of Carbofuran in Contaminated Soil by Immobilized Laccase. Polish Journal of Environmental Studies. 26 (3), 1305, 2017.

19. WANG Z., ZHONG M.G., WAN J.F., XU G.J., LIU Y. Development of attapulgite composite ceramsite/quartz sand double-layer biofilter for micropolluted drinking source water purification. International Journal of Environmental Science and Technology. 13 (3), 825, 2016.
20. BUCHANAN W., RODDICK F., PORTER N. Removal of VUV pre-treated natural organic matter by biologically activated carbon columns. Water Research. 42 (13), 3335, 2008.

21. MATHIEU L., BERTRAND I., ABE Y., ANGEL E., BLOCK J.C., SKALI-LAMI S, FRANCIUS G. Drinking water biofilm cohesiveness changes under chlorination or hydrodynamic stress. Water Research. 55, 175, 2014.

22. YANG B.M., LIU J.K., CHIEN C.C., SURAMPALLI R.Y., KAO C.M. Variations in AOC and microbial diversity in an advanced water treatment plant. Journal of Hydrology. 409 (1-2), 225, 2011.

23. GUO J.F., GUO P., Li S.M., LI X.J., LUO C.L., WANG H., JIANG Q. Screening an effective aerobic denitrification strain and its performance in MBR. Polish Journal of Environmental Studies. 26 (3), 1089, 2017.

24. ZHANG X.Q., LI Y.S., LI H. Enhanced Bio-Immobilization of $\mathrm{Pb}$ Contaminated Soil by Immobilized Bacteria with Biochar as Carrier. Polish Journal of Environmental Studies. 26 (1), 413, 2017.

25. CHIEN C.C., KAO C.M., CHEN C.W., DONG C.D., WU C.Y. Application of biofiltration system on AOC removal: Column and field studies. Chemosphere. 71 (9), 1786, 2008.

26. DALAHMEH S.S., JONSSON H., HYLANDER L.D., HUI N., YU D, PELL M. Dynamics and functions of bacterial communities in bark, charcoal and sand filters treating greywater. Water Research. 54, 21, 2014.

27. HAIG S.J., QUINCE C., DAVIES R.L., DOREA C.C., COLLINS G. Replicating the microbial community and water quality performance of full-scale slow sand filters in laboratory-scale filters. Water Research. 61, 141, 2014.

28. REUNGOAT J., ESCHER B.I., MACOVA M., KELLER J. Biofiltration of wastewater treatment plant effluent: Effective removal of pharmaceuticals and personal care products and reduction of toxicity. Water Research. 45 (9), 2751, 2011.

29. HO L., GRASSET C., HOEFEL D., DIXON M.B., LEUSCH F.D.L., NEWCOMBE G., SAINT C.P., BROOKES J.D. Assessing granular media filtration for the removal of chemical contaminants from wastewater. Water Research. 45 (11), 3461, 2011.

30. MENDEZ-DIAZ J.D., DAIEM M.M.A., RIVERAUTRILLA J., SANCHEZ-POLO M., BAUTISTATOLEDO I. Adsorption/bioadsorption of phthalic acid, an organic micropollutant present in landfill leachates, on activated carbons. Journal of Colloid and Interface Science. 369, 358, 2012.

31. HOYLAND V.W., KNOCKE W.R., FALKINHAM J.O., PRUDEN A., SINGH G. Effect of drinking water treatment process parameters on biological removal of manganese from surface water. Water Research. 66, 31, 2014.

32. ZHANG X.X., ZHANG Z.Y., MA L.P., LIU N., WU B., ZHANG Y., LI A.M., CHENG S.P. Influences of hydraulic loading rate on SVOC removal and microbial community structure in drinking water treatment biofilters. Journal of Hazardous Materals. 178 (1-3), 652, 2010.

33. HOWARD P.H., STITELER W.M., MEYLAN W.M., HUEBER A.E., BEAUMAN J.A., LAROSCHE M.E., BOETHLING R.S. Predictive model for aerobic biodegradability developed from a file of evaluated biodegradation data. Environmental Toxicology and Chemistry. 11 (5), 593, 1992. 